\title{
Analysis of coal dust combustion and gasification in the cyclone furnace
}

\author{
Robert Zarzycki ${ }^{1, *}$, and Zbigniew Bis $^{1}$ \\ ${ }^{1}$ Czestochowa University of Technology, Department of Energy Engineering, ul. Brzeznicka 60a, 42-201, Poland
}

\begin{abstract}
This study presents the design and operation of the cyclone furnace fuelled with coal dust. The main function of the furnace is coal dust gasification. The combustible gases that mainly contain $\mathrm{CO}$ can be used to feed a pulverized coal-fired boiler. The results of numerical calculations presented in the study demonstrated that cyclone furnace can operate over a wide range of fuel flow rates: from the conditions of coal dust combustion, which ensure maintaining the cyclone furnace in a state of hot reserve to the conditions of coal dust gasification, which allow for production of $\mathrm{CO}$. Gasification process helps control temperature under conditions of elevated oxygen concentration. The results allow for the use of the furnace to improve flexibility and coal dust operation through the reduction in its technological minimum.
\end{abstract}

\section{Introduction}

The examinations aimed to limit the environmental impact of the use of fossil fuels for electricity and heat generation have been conducted for many years. New technologies are being explored to help utilize chemical energy contained in the fuel more effectively. The analysed processes include oxy-fuel combustion $[1,2,3,4]$, on-ground and underground gasification [5] or construction of high-performance power units $[6,7]$.

One of the solutions which ensure further use of coal and steam power units with pulverized coal-fired boilers is to develop cyclone furnaces that are operated under oxy-combustion conditions with coal gasification [8]. Combustible gases generated during gasification ( $\mathrm{CO}$, $\mathrm{H}_{2}, \mathrm{CH}_{4}$ ) and supplied to the pulverized coal-fired boiler can be burnt in the boiler or, after preparation, used for other chemical processes as a raw material. Development of the renewable energy based on the use of wind causes rapid changes in production of electricity. Consequently, present and new energy power unit must be characterized by greater flexibility of changes in the load and possibly low minimum load.

This study presents the concept and opportunities for operation of the cyclone furnace for coal gasification to feed pulverized coal-fired boiler with the option of changing its load.

\section{Cyclone furnace}

Cyclone furnaces are power-generating devices with fuel combustion or gasification processes occurring in a strong eddy flow of gases. These furnaces have a relatively small combustion chambers compared to the equipment used in the energy sector. This allows for reaching high temperatures during the combustion process or during fuel gasification and for utilization of the furnaces for melting of the ash contained in the fuel.

Due to high temperatures that occur in cyclone furnaces, it is recommended to replace air with other oxidizing agents without nitrogen in order to limit $\mathrm{NO}_{\mathrm{x}}$ emissions. The use of recirculation of oxygen-rich flue gas or, additionally, water steam, substantially limits the emissions of $\mathrm{NO}_{\mathrm{x}}$.

Combustion in the oxygen-rich atmosphere leads to a considerable increase in temperature, with its values exceeding thermal strength of the ceramic materials used for construction of the furnace. Therefore, with higher oxygen concentrations, the temperature that can be obtained has to be controlled through: flue gas recirculation, combustion in the substoichiometric conditions (gasification), injection of water or water steam in order to reduce temperature (evaporation of water, overheating the steam) or the use of water steam in the process of coal gasification. Control of temperature through gasification of fuel inside the cyclone furnace helps obtain combustible gases composed mainly of $\mathrm{CO}$ and $\mathrm{H}_{2}$ with contents that depend on process conditions. Strong eddy makes it possible to elongate time of fuel stay in the combustion or gasification zone, thus limiting the waste of incomplete burning. With strong eddy motion, ash separation and vitrification in cyclone furnace is also feasible. After moving to the pulverized coal-fired boiler, hot combustible gases generated in the process of gasification $\left(\mathrm{CO}, \mathrm{H}_{2}\right)$ can support its operation or stabilize coal dust combustion process at low load. It is possible to supply gases generated to cyclone furnace in order to maintain the hot reserve state.

*Corresponding author: zarzycki@is.pcz.czest.pl 


\section{Process of coal dust combustion and gasification in cyclone furnace}

The process of coal dust combustion and gasification was performed in a cyclone furnace composed of two chambers: upper (PC2) and lower (PC1) [9,10,11]. The chamber $\mathrm{PC} 2$ is cylindrical. Its upper part features tangentially installed channels which supply fuel pneumatically in a stream of $\mathrm{CO}_{2}$ (recirculated flue gas). The chamber PC2 is also cylindrical. It is comprised of several steps with gradually reduced diameters. There are nozzles on lateral surfaces of the chamber PC1 which allow for supply of the "driving" gas with assumed composition of $\mathrm{O}_{2}$ and $\mathrm{CO}_{2}$. The chambers PC1 and PC2 are connected with a channel with a plunger used to separate the flow of flue gas from the chamber PC1 to PC2 and the fuel flow (carbon residue) from the chamber PC2 to PC1 (Fig. 1).

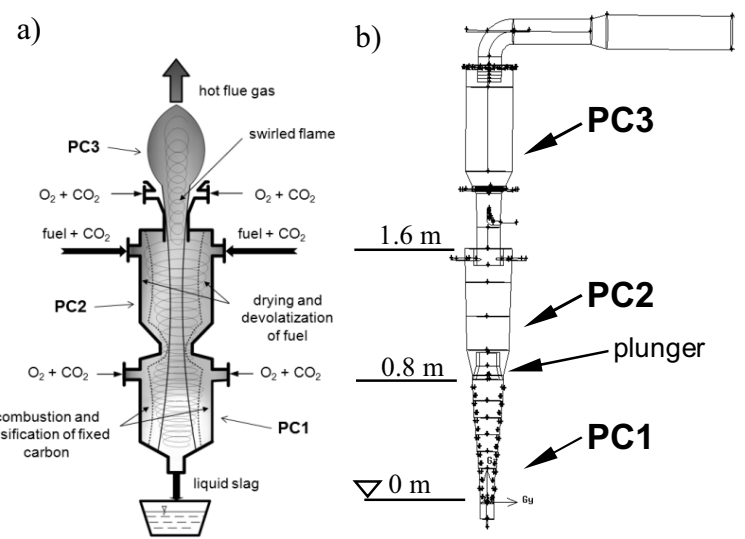

Fig. 1. Diagram (a) and view (b) of the model of a cyclone furnace with after-burner chamber.

The design of the cyclone furnace allows for:

- heating, drying and gasification of fuel in the chamber PC2;

- coal combustion or gasification process in the chamber PC1 which can be performed in the atmosphere of recirculated flue gas $\left(\mathrm{CO}_{2}\right.$ and $\left.\mathrm{O}_{2}\right)$.

In order to ensure effective fuel gasification, it is necessary to burn certain part of carbon residue in order to generate the required amount of heat for maintaining and control of endothermic reactions.

The results of numerical calculations of the coal dust combustion and gasification process in the atmosphere of $\mathrm{O}_{2}$ and $\mathrm{CO}_{2}$ represent part of the extensive experimental research and numerical calculations performed within the Strategic Programme „ADVANCED TECHNOLOGIES FOR ENERGY GENERATION" $[12,13,14,15,16,17,18]$.

The geometry of the cyclone furnace was designed using the Gambit software (Fig. 1b). Furthermore, the ANSYS FLUENT 14 software was also used for the calculations. Calculations of gas and fuel flow were performed using the Reynolds Stress turbulence model. Discrete Phase Model software was employed to model coal grain flow. Coal dust combustion and gasification was modelled using Species Transport model, which allows for modelling of chemical reactions both in the solid phase and gaseous phase [19,20,21,22,23]. Calculations were based on the radiation model termed Discrete Ordinate (DO). Calculations of the combustion process and gasification of coal dust with replacement diameter of $500 \mu \mathrm{m}$ were carried out for the fuel with physicochemical parameters presented in Table 1. For simplification purposes, it was adopted that the fuel does not contain sulphur. Reaction rate constants were derived from the studies $[20,21]$. Table 1 presents the parameters of the fuel used in the study.

Table 1. Results of technical and elemental analysis of the fuel used for simulations (dry state).

\begin{tabular}{|c|c|c|c|}
\hline $\begin{array}{c}\text { Technical } \\
\text { analysis }\end{array}$ & {$[-]$} & $\begin{array}{c}\text { Elemental } \\
\text { analysis }\end{array}$ & {$[-]$} \\
\hline VM & 0.45 & C & 0.85 \\
\hline FC & 0.45 & H & 0.1 \\
\hline A & 0.05 & O & 0.04 \\
\hline M & 0.05 & $\mathrm{~N}$ & 0.01 \\
\hline
\end{tabular}

Calculations for combustion and gasification of coal dust were described with the following reactions:

- Reaction of volatile matter combustion

$$
x_{1} \cdot \mathrm{VM}+x_{2} \cdot \mathrm{O}_{2}=y_{1} \cdot \mathrm{CO}+y_{2} \cdot \mathrm{H}_{2} \mathrm{O}+y_{3} \cdot \mathrm{N}_{2}
$$

where $x_{1}, x_{2}, y_{1}, y_{2}, y_{3}$ are stoichiometric coefficients

- Reaction of oxidation of carbon oxide

$$
\mathrm{CO}+0.5 \mathrm{O}_{2}=\mathrm{CO}_{2}
$$

- Reaction of oxidation of fixed carbon (FC)

$$
\mathrm{C}_{(s)}+0.5 \mathrm{O}_{2}=\mathrm{CO}
$$

- Boudouard's reaction

$$
\mathrm{C}_{(s)}+\mathrm{CO}_{2}=2 \mathrm{CO}
$$

- Synthesis of water gas

$$
\mathrm{C}_{(s)}+\mathrm{H}_{2} \mathrm{O}=\mathrm{CO}+\mathrm{H}_{2}
$$

- Hydrogen oxidation reaction

$$
\mathrm{H}_{2}+0.5 \mathrm{O}_{2}=\mathrm{H}_{2} \mathrm{O}
$$

Conditions of coal dust gasification process modelling were as follows: flow of coal dust with mean grain size of $500 \mu \mathrm{m}$ of 0.2 to $2 \mathrm{~kg} / \mathrm{s}$ supplied tangentially with two inlets located at the opposite sides of the chamber PC2 (Fig. 1) in the $\mathrm{CO}_{2}$ with temperature of $350 \mathrm{~K}$ and the velocity of $3 \mathrm{~m} / \mathrm{s}$. Following a helical line, the fuel moves downwards in the chamber PC2 as it is heated, dried and devolatilized through the effect of hot flue gas that flows in the furnace axis and contact with hot walls of the chamber PC2. Fuel gasification occurs through partial combustion of fixed carbon (FC) in the chamber PC1 $[10,12,13,14,15,17,18]$. The driving nozzles were used to supply (tangentially) the driving gas composed of the mixture of $\mathrm{O}_{2} / \mathrm{CO}_{2}$ with volumetric content of $60 / 40 \%$ with the velocity of $3 \mathrm{~m} / \mathrm{s}$ and temperature of $600 \mathrm{~K}$.

The numerical model takes into consideration the heat transfer through furnace walls to its surroundings. Actual thickness of individual components of the laboratory furnace was also assumed during calculation of heat loss, with coefficients of heat penetration and conduction for the materials. It was assumed that air temperature around the furnace is $300 \mathrm{~K}$. 


\section{Analysis of coal dust combustion and gasification for variable fuel flow rate}

The aim of the results presented in this study was to determine conditions of cyclone furnace operation at variable fuel flow rate in order to examine opportunities for control of the stream. For this purpose, a series of numerical simulations were performed for the flow rate supplied to the coal dust furnace ranging from 0.2 to $2 \mathrm{~g} / \mathrm{s}$.

Figures 2-6 present distribution of selected process values for three mass loads with the fuel flow rate to the furnace $(0.2,0.8$ and $2 \mathrm{~g} / \mathrm{s})$. The driving gas which is tangentially supplied along the level of the chamber $\mathrm{PC} 1$, characterized by the $\mathrm{O}_{2} / \mathrm{CO}_{2}$ ratio of $60 / 40 \%$, causes a strong eddy motion of the gas and fuel. Due to the effect of the centrifugal force, fuel is accumulated near the walls of the chambers PC1 and PC2, which is presented in Fig. 2.

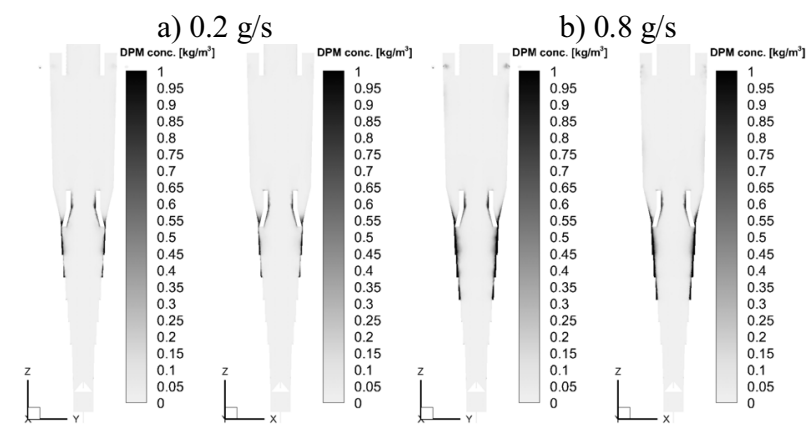

c) $2 \mathrm{~g} / \mathrm{s}$

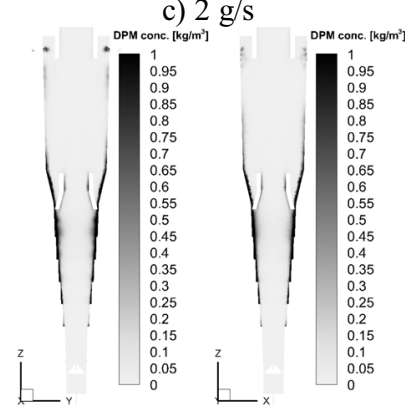

Fig. 2. Distributions of fuel concentration.

It can be observed that the increase in the mass flow rate of the fuel supplied to the furnace leads to the increase in the thickness of its layer on the walls and its transport towards the lower part of the furnace. The maximal fuel flow rate can be determined based on the maximal flow rate of the fuel supplied to the furnace and gasified without generation of the loss of incomplete combustion. The use of the stepped chamber PC1 allows for maintaining a substantial fuel mass in a state of eddy. The zone where fuel is present significantly depends on the amount of the oxidant. If the fuel flow rate increases, the demand for the oxidant is higher (see Fig. 3). The zone with elevated oxygen concentration reduces with the increase in fuel flow rate (Fig. 3). Increased oxygen content in the chamber PC2 can be also observed for the flow rate of $0.2 \mathrm{~g} / \mathrm{s}$, which reflects the presence of substoichiometric conditions in the chamber PC1 (see Fig. 3a). This leads to the increase in the concentration of $\mathrm{CO}_{2}$ and low values of $\mathrm{CO}$ in the chamber PC2 (Figs. 5a and 6a). The highest temperature is observed in the upper part of the PC1 chamber (see Fig. 4a), reaching the chamber $\mathrm{PC} 2$.

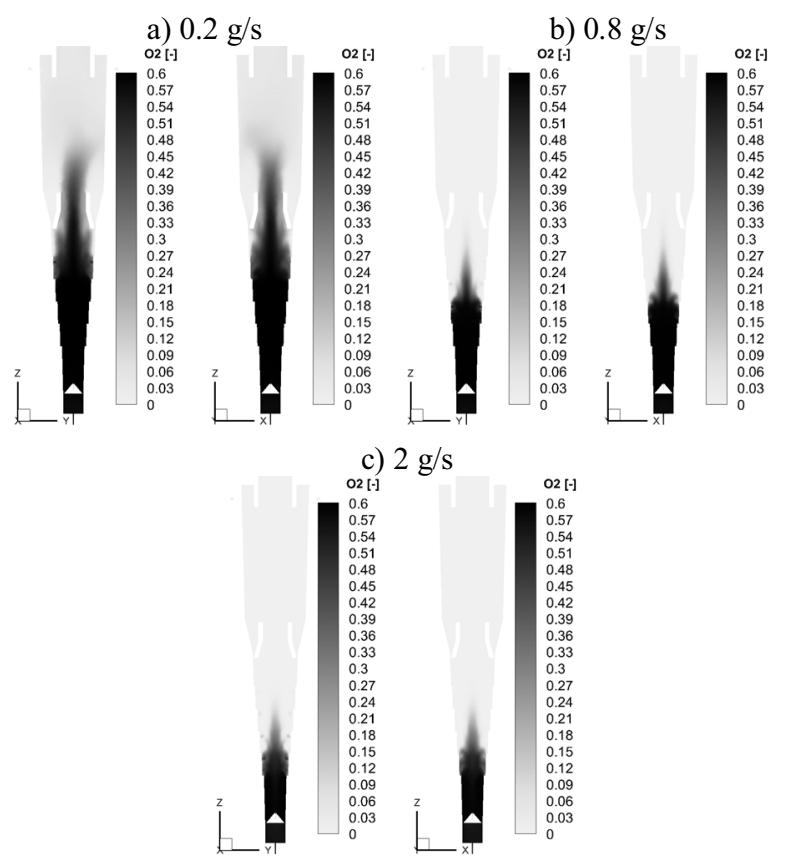

Fig. 3. Distributions of molar fractions of $\mathrm{O}_{2}$.

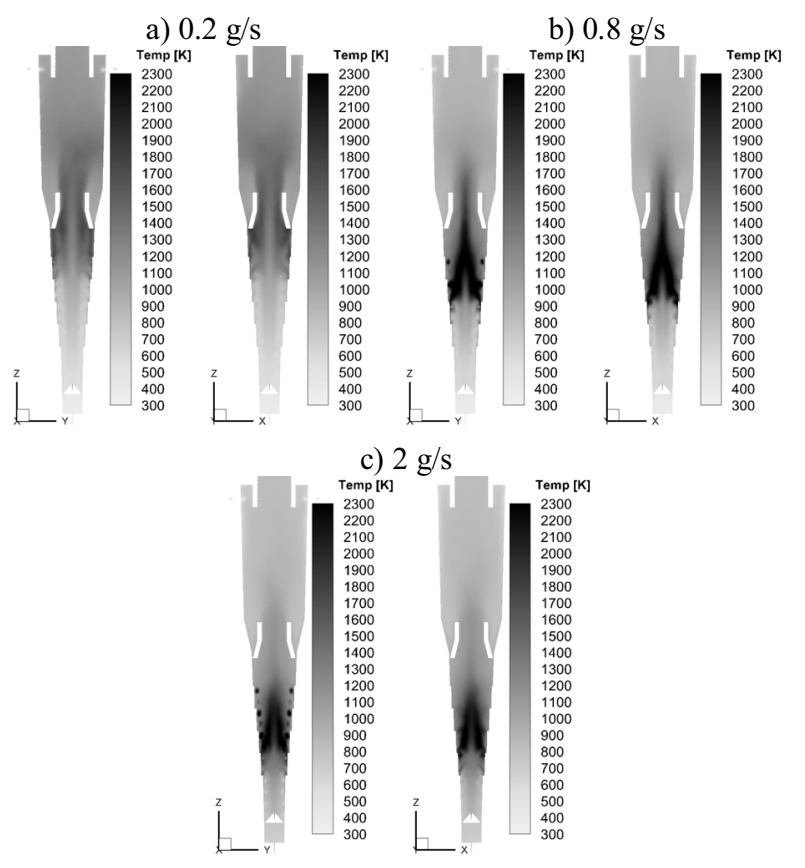

Fig. 4. Temperature distributions.

For the presented load of the furnace with the fuel flow rate of 0.8 and $2 \mathrm{~g} / \mathrm{s}$, the zone of high oxygen concentrations is significantly reduced and moving towards the lower part of the chamber PC1 (see Figs. 3b, $3 \mathrm{c})$. In these cases, the process in the chamber PC1 occurs under substoichiometric conditions and is conductive to coal gasification process. The area of the highest temperatures is shifted to the central part of the chamber PC1 (Figs. 4b, 4c). High concentration of $\mathrm{O}_{2}$ (Figs. 3b, 3c) and $\mathrm{CO}_{2}$ (Figs. 6b, 6c) (resulting from the gas supplied) is observed below this area, whereas above 
the area of high temperature, the content of $\mathrm{O}_{2}$ declines virtually to zero (Figs. 3b, 3c), while the content of $\mathrm{CO}_{2}$ decreases (Figs. 6b, 6c) as a result of the reaction (6) and the $\mathrm{CO}$ content rises (Figs. 5b, 5c).

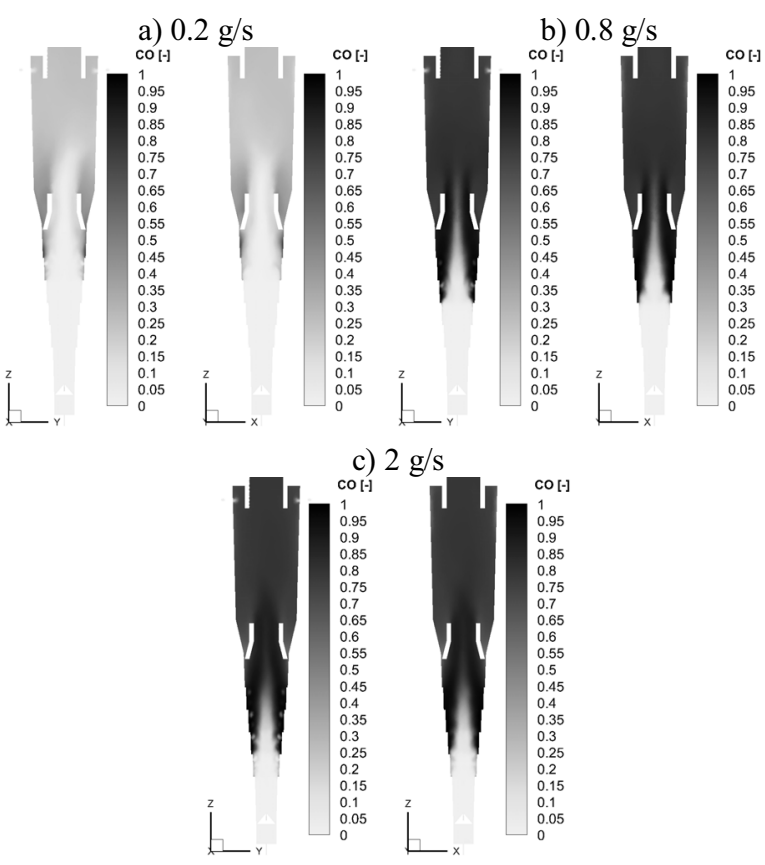

Fig. 5. Distributions of molar fractions of CO.
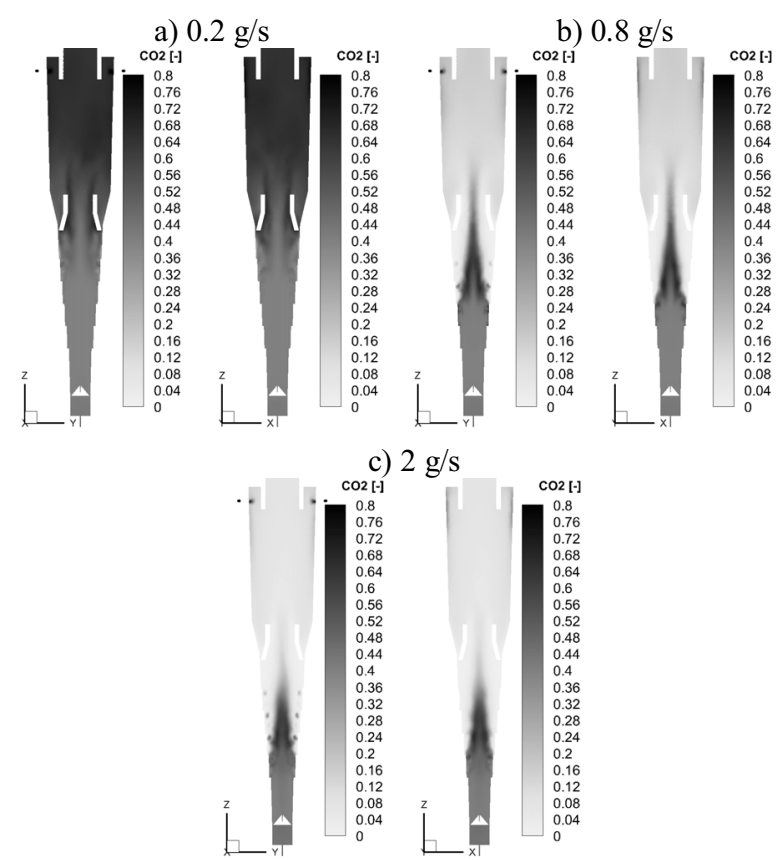

Fig. 6. Distributions of molar fractions of $\mathrm{CO}_{2}$.
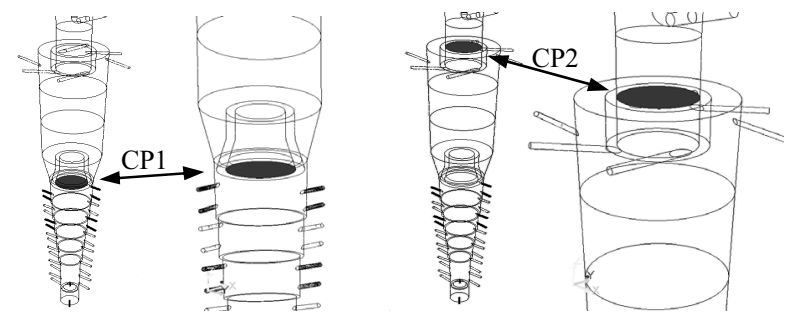

Fig. 7. Location of $\mathrm{CP} 1$ and $\mathrm{CP} 2$ planes.
These observations are supported by the profiles of mean values of selected parameters at the outlets from the chambers PC1 and PC2 (Fig. 7). The contents of $\mathrm{O}_{2}$ presented in Fig. 8a show that the combustion process in the chamber PC1 occurs for the adopted aerodynamic conditions up to the fuel flow rate of ca. $0.4 \mathrm{~g} / \mathrm{s}$. This observation is also supported by the fact that the temperature maximum occurs in the planes $\mathrm{CP} 1$ and $\mathrm{CP} 2$ (Fig. 8b). Furthermore, a relatively low CO content (Fig. 9a) and high $\mathrm{CO}_{2}$ content (Fig. 9b) are noticeable for fuel flow rates below $0.4 \mathrm{~g} / \mathrm{s}$. Very low $\mathrm{H}_{2}$ contents are also observed in this area (Fig. 10a) in the planes CP1 and $\mathrm{CP} 2$, resulting from oxidation of hydrogen by the oxygen contained in the gases. A close to zero content of volatile matter in the plane CP1 (resulting from their oxidation) is also observed (see Fig. 10b). a)

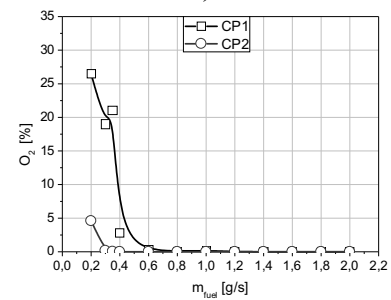

b)

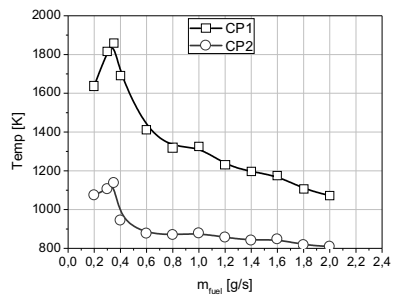

Fig. 8. Changes in mean values of (a) $\mathrm{O}_{2}$ content and (b) temperature in the planes $\mathrm{CP} 1$ and $\mathrm{CP} 2$ versus fuel flow rate. a)

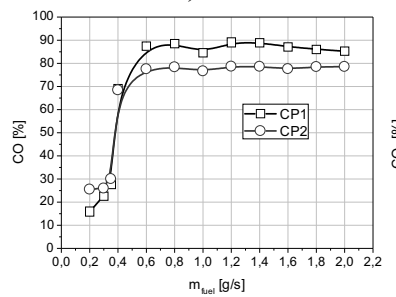

b)

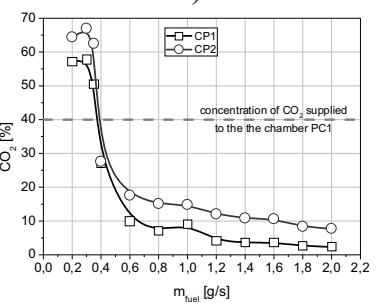

Fig. 9. Changes in mean values of (a) $\mathrm{CO}$ content and (b) $\mathrm{CO}_{2}$ content in the planes $\mathrm{CP} 1$ and $\mathrm{CP} 2$ versus fuel flow rate.

For the fuel mass flow rate of over $0.4 \mathrm{~g} / \mathrm{s}$ in the control plane $\mathrm{CP} 1$ and $\mathrm{CP} 2, \mathrm{O}_{2}$ concentration is close to zero (Fig. 8a). A significant decline in temperature (Fig. $8 b$ ) in the CP1 plane is observed, resulting, on the one hand, from the movement of the gasification front and, on the other hand, from the intensive heat consumption during endothermic reactions. It is noticeable that, regardless of the flow rate for the gasified fuel stream, CO content (Fig. 9a) at the outlet from the chamber PC2 reaches $80 \%$. Furthermore, a decline in $\mathrm{CO}_{2}$ content (Fig. 9b) in the planes CP1 and CP2 is also observed for increasing fuel mass flow rates. This results from the increased demand for the flow rate of the gasifying medium for higher fuel flow rates. Figs. 10a and 10b illustrate the concentration of $\mathrm{H}_{2}$ and volatile matter $(\mathrm{VM})$, respectively. For the fuel flow rate of over $0.4 \mathrm{~g} / \mathrm{s}$, the analysed values are nearly linear, which means that their amount is proportional to the flow rate of the fuel supplied and, apart from the initial area (below $0.4 \mathrm{~g} / \mathrm{s}$ ), these substances do not take part in the processes of gasification and oxidation. 
For the fuel flow rates from 0.2 to $1.6 \mathrm{~g} / \mathrm{s}$, no fuel outflow from the PC1 to the slag bath was found, which suggests complete fuel conversion. It was found that for the fuel flow rate of 1.8 and $2 \mathrm{~g} / \mathrm{s}$, non-reacted fuel leaves the chamber PC1 at the flow rate of $0.0275 \mathrm{~g} / \mathrm{s}$ and $0.0498 \mathrm{~g} / \mathrm{s}$, which represents ca. $1.5 \%$ and $2.5 \%$ of the flow rate of the supplied fuel. a)

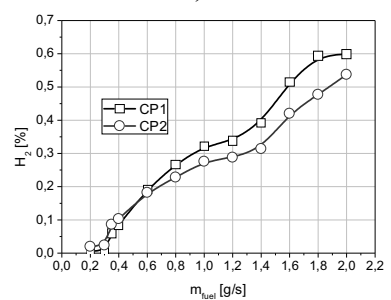

b)

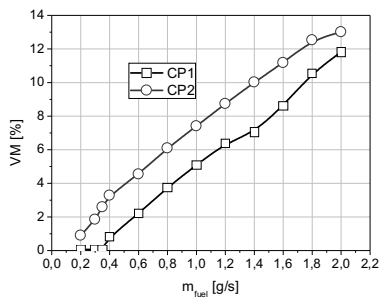

Fig. 10. Changes in mean values of (a) $\mathrm{H}_{2}$ content and (b) VM in the planes $\mathrm{CP} 1$ and $\mathrm{CP} 2$ versus fuel flow rate.

\section{Conclusion}

The results of numerical calculations presented in the study demonstrated that, through changes in the mass flow rate of the coal dust supplied to the cyclone furnace, it is possible to obtain the convenient conditions for its combustion or gasification. Consequently, coal dust combustion can be performed at low mass flow rates, which causes that the cyclone furnace can be maintained in a state of hot reserve, thus generating hot flue gas and combustible gases with low $\mathrm{CO}$ contents (ca. 30\%). Furthermore, at elevated fuel flow rates, coal dust gasification can be easily performed, with the $\mathrm{CO}$ concentrations at the outlet from the chamber PC2 reaching $80 \%$ and high content of volatile matter (ca. $13 \%$ ). The combustible gases supplied to the chamber of the pulverized coal-fired boiler can be used to stabilize coal dust combustion process at low boiler load. They can replace the operation of the dust burners or ignition burners at low load while opening up the opportunities for maintaining the boiler in the hot reserve state and ensuring lower levels of the minimum load in the pulverized coal-fired boiler.

\section{Acknowledgements}

\section{BS/PB-404-301/11}

\section{References}

1. W. Nowak, T. Czakiert, Spalanie tlenowe dla kottów pylowych $i$ fluidalnych zintegrowanych $z$ wychwytywaniem $\mathrm{CO}_{2}$, Wydawnictwo Politechniki Częstochowskiej, Częstochowa, (2012)

2. W. Nowak, W. Rybak, T. Czakiert, Spalanie tlenowe dla kotlów pylowych $i$ fluidalnych zintegrowanych z wychwytywaniem $\mathrm{CO}_{2}$. Kinetyka $i$ mechanizm spalania tlenowego oraz wychwytu $\mathrm{CO}_{2}$, Wydawnictwo Politechniki Częstochowskiej, Częstochowa, (2013)

3. W. Nowak, M. Chorowski, T. Czakiert, Spalanie tlenowe dla kottów pylowych $i$ fluidalnych zintegrowanych z wychwytywaniem $\mathrm{CO}_{2}$. Produkcja tlenu na potrzeby spalania tlenowego, Wydawnictwo Politechniki Częstochowskiej, Częstochowa, (2014)

4. W. Nowak, M. Ściążko, T. Czakiert, Spalanie tlenowe dla kotłów pylowych $i$ fluidalnych zintegrowanych $z$ wychwytywaniem $\mathrm{CO}_{2}$. Doświadczenia $z$ instalacji pilotowych $i$ perespektywy dla instalacji demonstracyjnych, Wydawnictwo Politechniki Częstochowskiej, Częstochowa, (2015)

5. T. Borowiecki, J. Kijeński, J. Machnikowski, M. Ściążko, Czysta energia, produkty chemiczne $i$ paliwa z węgla - ocena potencjału rozwojowego, Instytut Chemicznej Przeróbki Węgla, Zabrze, (2008)

6. T. Chmielniak, H. Łukowicz, Modelowanie $i$ optymalizacja węglowych bloków energetycznych $z$ wychwytem $\mathrm{CO}_{2}$, Wydawnictwo Politechniki Śląskiej, Gliwice, (2015)

7. A. Rusin, Wybrane aspekty eksploatacji $i$ diagnostyki bloków energetycznych nowych generacji, Wydawnictwo Politechniki Śląskiej, Gliwice, (2015)

8. R. Zarzycki, R. Kobyłecki, M. Kratofil, Z. Bis, Kierunki rozwoju palenisk cyklonowych, Polityka Energetyczna tom 17, z. 4. 2014. Wyd. Instytutu GSMiE PAN, Kraków, pp. 249 - 261

9. Z. Bis, R. Kobyłecki, R. Zarzycki, Urządzenie do spalania $i$ zgazowania paliw stałych, Zgłoszenie wynalazku P.411668, 2015

10. R. Zarzycki, Z. Bis, R. Kobyłecki, The concept of coal burning in a cyclone furnace, IX ICCHME, 2326 May 2016, Cracow, Poland, no. 492

11. R. Kobyłecki, R. Zarzycki, Z. Bis, Przedpalenisko cyklonowe dla spalania $i$ zgazowania pytu węglowego, Wydawnictwo ITC, Energetyka Gazowa tom 2, 2016, pp. 277-285

12. R. Zarzycki, Z. Bis, Modelling of the process of coal dust combustion in a cyclone furnace, IX ICCHME, 23-26 May 2016, Cracow, Poland, no. 493

13. R. Zarzycki, Z. Bis, Modelling of coal dust gasification in a cyclone furnace under oxy-fuel combustion conditions, IX ICCHME, 23-26 May 2016, Cracow, Poland, no. 494

14. R. Zarzycki, P. Warzecha, R. Kobyłecki, Z. Bis, Modelowanie matematyczne $i$ symulacje numeryczne tlenowego spalania wegla oraz zgazowania w przedpalenisku cyklonowym, Spalanie tlenowe dla kotłów pyłowych i fluidalnych zintegrowanych $\mathrm{z}$ wychwytem $\mathrm{CO}_{2}$, seria Monografie nr 301, Częstochowa 2015, pp. 310 334

15. R. Zarzycki, Z. Bis, Modelowanie procesu spalania $i$ zgazowania pylu węglowego $w$ palenisku cyklonowym, Wydawnictwo ITC, Energetyka Gazowa tom 2, 2016, s. 361-376

16. R. Zarzycki, M. Kratofil, D. Pawłowski, M. Ścisłowska, R. Kobyłecki, Z. Bis, Analiza wyników obliczeń numerycznych przeptywu pylu weglowego oraz gazu w palenisku cyklonowym, Polityka Energetyczna, t. 16, zeszyt 3, 2013, s. 301-312 
17. R. Zarzycki, Z. Bis, Modelling of coal dust gasification using the water steam in a cyclone furnace, Proceedings of the 4th International Conference on Contemporary Problems of Thermal Engineering, 14-16 September 2016, Katowice, Poland, ISBN 978-83-61506-36-2, p. 861-871

18. R. Zarzycki, M. Kratofil, D. Pawłowski, M. Ścisłowska, R. Kobyłecki, Z. Bis, Analiza wyników obliczeń numerycznych przepływu pyłu węglowego oraz gazu w palenisku cyklonowym, Polityka Energetyczna, t. 16, zeszyt 3, 2013, s. 301-312

19. D. Toporov, P. Bocian, P. Heil, A. Kellermann, H. Stadler, S. Tschunko, M. Förster, R. Kneer, Detailed investigation of a pulverized fuel swirl flame in $\mathrm{CO}_{2} / \mathrm{O}_{2}$ atmosphere, Combustion and Flame (2008) vol. 155 , pp. 605-618

20. M. Vascellari, G. Cau, Numerical simulation of pulverized coal oxycombustion with exhaust gas recirculation, Proceeding of CCT2009 Fourth International Conference on Clean Coal Technologies. Dresden, Germany (2009)

21. L. Chen, M. Gazzino, A.F. Ghoniem, Characteristics of pressurized oxy-coal combustion under increasing swirl number, 35th International Technical Conference on Coal Utilization \& Fuel Systems. Clearwater, Florida (2010)

22. P. Warzecha, A. Bogusławski, Symulacje numeryczne spalania pylu weglowego $w$ atmosferze $\mathrm{O}_{2}-\mathrm{CO}_{2}$, Archiwum Spalania, 2012, Vol. 12, nr 3 pp. 145-151

23. ANSYS Fluent Theory Guide, 2011 